\title{
Luminescence chronology of the Grub-Kranawetberg site, Austria
}

\author{
Ludwig Zöller, Daniel Richter, Stefanie Masuth, Lisa Wunner, Manfred Fischer, Walpurga Antl-Weiser
}

How to cite:

Zöller, L., Richter, D., Masuth, S., Wunner, L., Fischer, M., Antl-Weiser, W. (2013): Luminescence chronology of the GrubKranawetberg site, Austria. - E\&G Quaternary Science Journal, 62 (2): 127-135. DOI: 10.3235/eg.62.2.04

Abstract:

\begin{abstract}
Eight samples from a loess profile at the open air site of Grub-Kranawetberg (Lower Austria) were dated by Infrared Stimulated Luminescence (IRSL) of the polymineral fine-grain $(4-11 \mu \mathrm{m})$ fraction and Optically Stimulated Luminescence (OSL) of quartz grains in the size range of $38-63 \mu \mathrm{m}$. Calibrated radiocarbon ages of ca. $30 \mathrm{ka} \mathrm{BP}$ on charcoal from the main archaeological layer AH4 agree with the IRSL and OSL age estimates within error limits. Anomalous fading of the feldspar-dominated IRSL from fine grain fraction could not be detected in the laboratory and the MAAD-IRSL ages were therefore not corrected. Most IRSL and OSL ages agreed within error limits, however, some IRSL ages were significantly underestimated as compared to the OSL ages, and in general the mean of the OSL ages was higher compared to the mean of individual IRSL ages. The OSL ages place the deposition of the exposed loess including an interstadial pedocomplex ("Stillfried B") to between ca. $47 \mathrm{ka}$ and ca. $30 \mathrm{ka}$. Potential pedostratigraphic correlations with some European loess areas as well as palaeoecological implications on Upper Palaeolithic human occupation patterns are discussed.
\end{abstract}

\section{Lumineszenz-Chronologie der Fundstelle Grub-Granawetberg, Österreich}

Das Alter von acht Proben aus einem Lössprofil der Freilandfundstelle Grub-Kranawetberg (Niederösterreich) wurde mittels der Lumineszenzmethoden der IRSL-Datierungen an der polymineralischen Feinkornfraktion und der OSL-Datierungen an der Mittelkornfraktion von Quarzen bestimmt. Kalibrierte Radiokohlenstoffalter von ca. 30 ka für den archäologischen Hauptfundhorizont AH4 werden innerhalb der Fehlergrenzen durch IRSL- und OSL-Alter bestätigt. Anomales Ausheilen der feldspat-dominierten Feinkornfraktion konnte im Labor nicht nachgewiesen werden, weshalb die MAAD-IRSL Alter nicht korrigiert wurden. Während die meisten IRSL- und OSL-Alter innerhalb ihrer Fehlergrenzen übereinstimmen, unterschätzen einige IRSL-Alter die OSL-Alter aus bisher unbekannten Gründen signifikant, wobei die Mittelwerte der OSL-Resultate tendenziell älter als die IRSLDatierungen sind. Nach den OSL-Altern wurde der aufgeschlossene Löss einschließlich eines interstadialen Bodenkomplexes (,Stillfried B“) im Zeitraum zwischen ca. $47 \mathrm{ka}$ und ca. 30 ka gebildet. Mögliche pedostratigraphische Korrelationen mit einigen europäischen Lössgebieten sowie paläoökologische Überlegungen zur menschlichen Besiedlung im Jungpaläolithikum werden diskutiert.

Keywords: $\quad$ Luminescence dating, Grub-Kranawetberg, loess, palaeoecology, Stillfried B, correlations

Addresses of authors: L. Zöller*, D. Richter, S. Masuth, L. Wunner, M. Fischer, Geomorphology Chair, University of Bayreuth, Germany W. Antl-Weiser, Naturhistorisches Museum Wien, Prähistorische Abteilung, Vienna, Austria. D. Richter, Department of Human Evolution, Max Planck Institute for Evolutionary Anthropology, Leipzig, Germany.

*corresponding author: ludwig.zoeller@uni-bayreuth.de

\section{Introduction}

The Lower Gravettian open air site of Grub-Kranawetberg (Lower Austria) has been studied since the mid-1990. The site is described and discussed in detail in ANTL-WEISER (this volume). The age of the archaeological horizons, in particular of the main horizon AH4 attributed to the Gravettian period, is constrained by several radiocarbon ages. Further minor archaeological assemblages located a few $\mathrm{cm}$ above AH4 and labelled as "first upper AH" are followed by the "second upper AH" (ANTL-WEISER 2008). Another human occupation was detected $20 \mathrm{~cm}$ below $\mathrm{AH} 4$ (Lower layer in Table 4). A section of ca. $210 \mathrm{~cm}$ thick brownish loess loam was observed from ca. $30 \mathrm{~cm}$ below AH4 and is interpreted as a pedocomplex, probably related to Stillfried-B. A more detailed pedological analysis is however pending. The timing of the deposition of the under- and overlying loess, the occurrence of potential sedimentation hiatuses, and relative sedimentation rates were unknown so far. A contribution to these questions is attempted here by luminescence dating within the framework of an interdisciplinary team using a diachronic landscape reconstruction approach (WATERS 1996), which examined the entire profile of the 2010 and 2011 excavations. The present contribution tries to unravel the chronostratigraphy and geochronology of the site within the Danube loess sequence of Austria and relates these to palaeoecological interpretations.

\section{Sampling}

The Kranawetberg-site is situated west of the village Grub on the western side of the March River at N $48^{\circ} 25^{\prime} 08^{\prime \prime}$ and E $16^{\circ} 50^{\prime} 02$ ", altitude $185 \mathrm{~m}$ a.s.l. Samples for optical dating (IRSL, OSL) were extracted from the excavation site (for lo- 
cation see ANTL-WEISER 2008) by one of us (W.A.-W.) during the summer of 2010. Coordinates of the sampled profile O16 relative to the reference point of the excavation are $\mathrm{x}=15.07$ and $y=15.86 \mathrm{~m}$. Steel cylinders of $100 \mathrm{~cm}^{3}$ volume were hammered horizontally into the loess wall and sealed by lighttight lids. One of the main research focus was the verification of the radiocarbon dating of the main archaeological horizon (AH 4). Luminescence dating of such a horizon, that would have been mixed by the prehistoric anthropogenic activities, is considered as difficult. Thus, the sampling was performed at positions in 'clean' loess directly above and below this horizon. These were with the aim to provide bracketing ages. Further to understand the sedimentation history, additional samples were taken wherever feasible, in the entire available profile.

\section{Sample preparation and IRSL/OSL measurements}

Sample preparation for luminescence measurements were carried out in the dark laboratory under subdued red diode light $(640 \pm 20 \mathrm{~nm})$. Approximately $1 \mathrm{~cm}$ of material from each end of the cylinders was scraped off and used for dosimetry measurements using thick source alpha counting to determine $U$ and Th contents (ZöLler \& PERNICKA 1989) and ICP-MS (for K contents). Samples were then pretreated with $1 \mathrm{~N} \mathrm{HCl}$ and $30 \% \mathrm{H}_{2} \mathrm{O}_{2}$, followed by wet sieving and extraction of the 4-11 $\mu \mathrm{m}$ polymineral fine-grain fraction in Atterberg cylinders using Stoke's law. IRSL dating was carried out using the MAAD (Multiple Aliquot Additive Dose) protocol following MAUz et al. (2002), with further experimental details given in Fuchs et al. (2008). IRSL measurements were carried out on a Risø TL/ OSL-DA15 reader equipped with a Chroma D410 detection filter (transmission over $425 \pm 15 \mathrm{~nm}$ band). The use of a MAAD protocol ensured that sensitivity changes were not an issue. All aliquots, including the ones for the fading experiment, were preheated at $220^{\circ} \mathrm{C}$ for $300 \mathrm{~s}$ before IRSL measurement. No normalization was required due to good reproducibility of the luminescence signals of the 5-6 aliquots for each of the additive dose points of 70, 140, 280 and 560 Gy. For data processing and calculation of equivalent doses by exponential fitting and extrapolation we used the Analyst (3.07b) software supplied with the Risø reader and followed MAUz et al. (2002). All aliquots used for the construction of the MAAD growth curve (Figure 5) were stored at $70^{\circ} \mathrm{C}$ for one week between laboratory irradiation and IRSL measurements, to allow for the decay of short lived IRSL signals and also permit for the occurrence of any potential short term anomalous fading. Such a procedure in general equals storage of 4 weeks at room temperature (BERGER 1988, p. 26). A fading test was carried out by measuring the IRSL of 5 additional aliquots which had received the largest additive laboratory dose (ca. 560 Gy) immediately after irradiation and comparing this IRSL signal intensity with the signal from stored aliquots of the same dose group, which were used for the construction of the MAAD growth curve. The percentage of fading was calculated as the ratio of the intensities $(\mathrm{N}+\mathrm{B}+$ delay $) /(\mathrm{N}+\mathrm{B})$ of the IRSL-signal for each sample except BT 1009, which failed due to machine error.

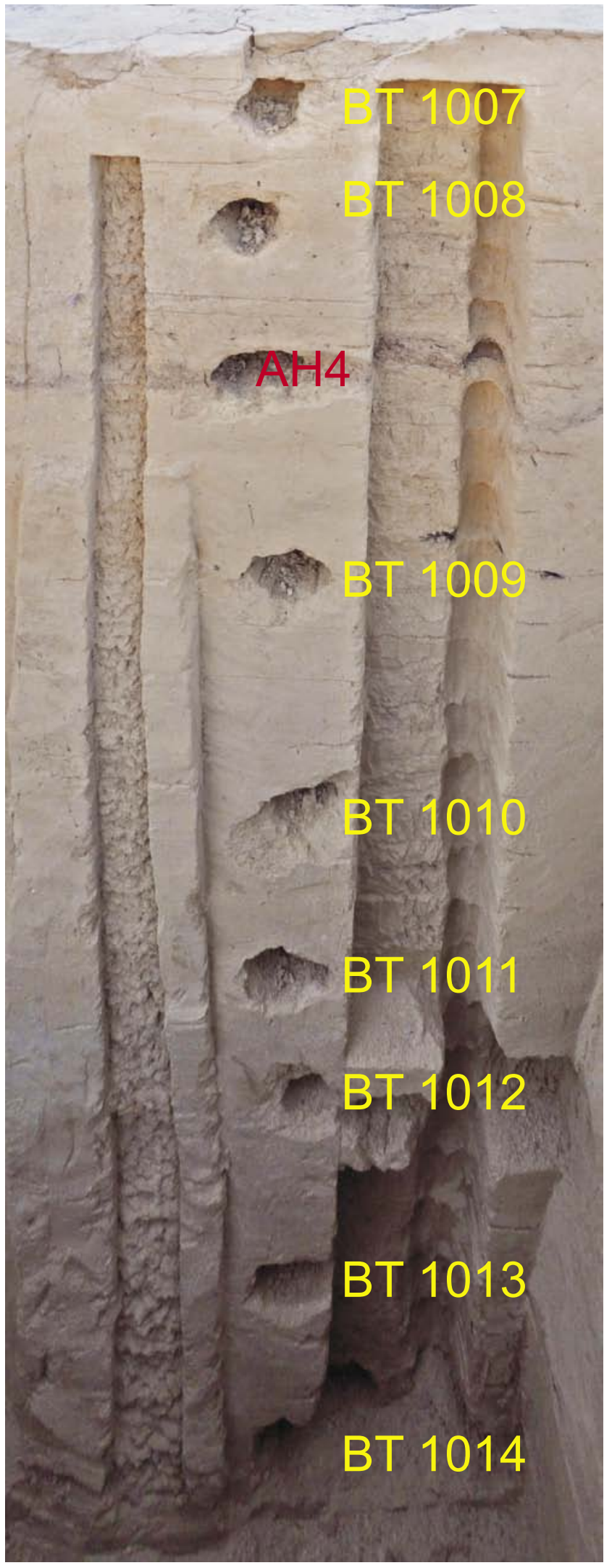

Fig. 1: Loess section of the Grub-Kranawetberg excavation 2010 and sample numbers. Note the reddish-yellow hue below and partly also above the main Archaeological Layer AH 4 and the increasing reddish-brown hue below sample BT 1012 indicating weak interstadial soil formation.

Abb. 1: Lössprofil von der Grabung Grub-Kranawetberg 2010 und Probennummern. Man beachte den rötlich-gelblichen Farbton unterhalb und teilweise auch oberhalb des Archäologischen Fundhorizontes AH 4 sowie den zunehmend rötlich-braunen Farbton unterhalb der Probe BT 2012 als Hinweise auf schwache interstadiale Bodenbildung. (Foto: W. Antl-Weiser) 


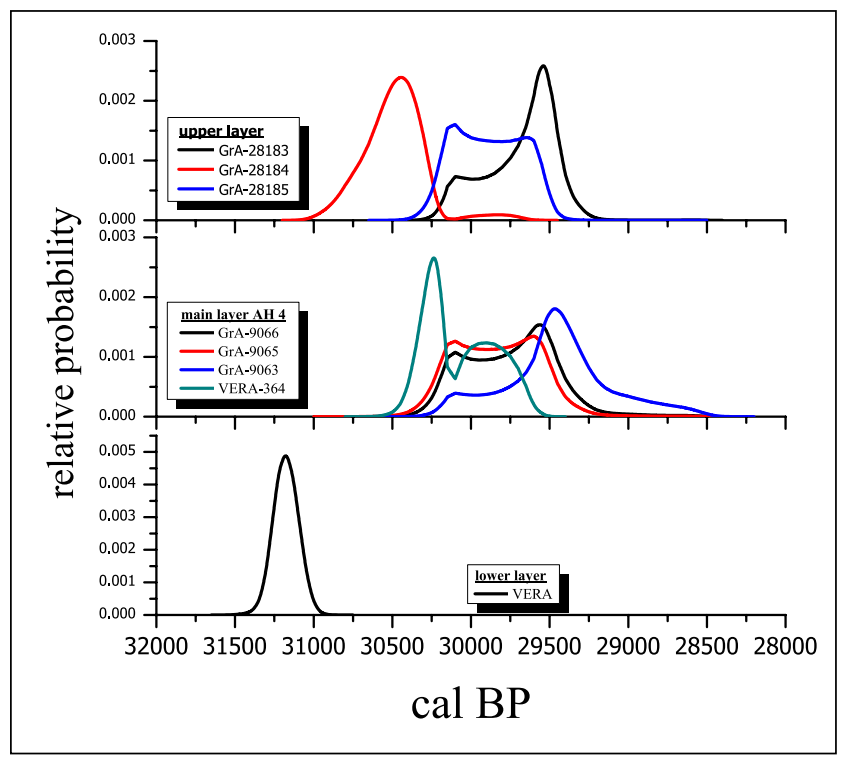

Fig. 2: Cumulative (black line, not normalized) and single (coloured) probability distributions of calibrated ${ }^{14} \mathrm{C}$ ages from the Grub-Kranawetberg site (Calib 6.11 with IntCalo9).

Abb. 2: Kumulative Wahrscheinlichkeitsverteilungen (schwarz, unnormiert) und einzelne Wahrscheinlichkeitsverteilungen (farbig) der kalibrierten ${ }^{14} \mathrm{C}$ Alter von der Fundstelle Grub-Kranawetberg (Calib 6.11 mit IntCal09).

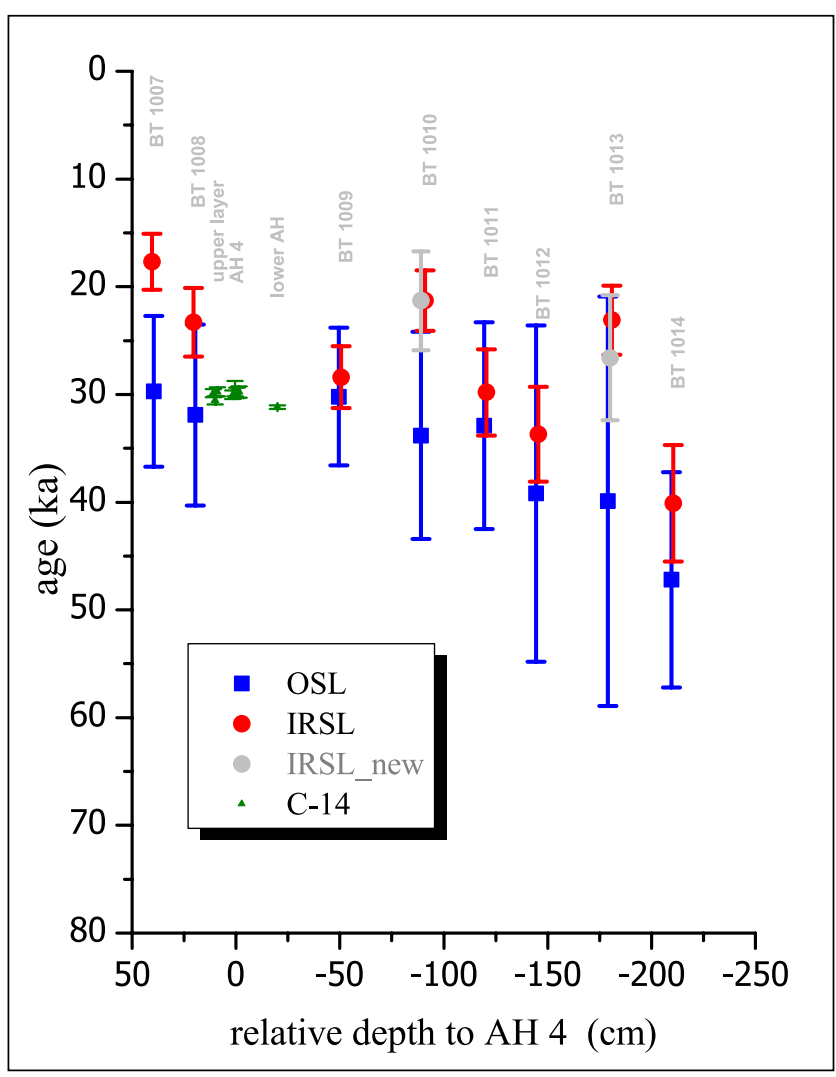

Fig. 3: Age-depth plot of ${ }^{14} \mathrm{C}$ (calibrated), OSL and IRSL ages (2- $\left.\sigma\right)$. Sample depth positions were slightly shifted for clarity.

Abb. 3: Alters-Tiefenplot von ${ }^{14} \mathrm{C}$ (kalibriert) -, OSL- und IRSL-Altern (2- $\sigma$ ). Probenpositionen wurden zur besseren Sichtbarkeit leicht versetzt dargestellt.
The quartz extracts from the middle grain size fraction (38-63 $\mu \mathrm{m})$ were obtained by wet sieving and etching in hydrofluoric acid $\left(\mathrm{H}_{2} \mathrm{SiF}_{6}\right)$ following FucHs et al. (2005) for OSL measurement by blue light stimulation. Feldspar contamination was ruled out by IRSL measurements yielding intensities at background level. OSL measurements followed the SAR protocol (MURRAY \& WINTLE 2000) and experimental details as described in FucHs et al (2012), including analytical details like acceptance criteria etc. A preheat of $200^{\circ} \mathrm{C}$ for $10 \mathrm{~s}$ was applied. Due to the scarcity of quartz middle grains size, the study was hampered by the low number of aliquots available for $\mathrm{D}_{\mathrm{E}}$-determination. Results from only 10-22 aliquots (excluding $0-10 \%$ rejection) could be obtained, and these resulted in relatively larger uncertainties and precluded elaborate statistical analysis of the $D_{E}$ data.

\section{Results \\ 4.1 Dosimetry Results}

Dose-rates were calculated assuming secular equilibrium of $U$ decay series and using conversion factors given by Guerin et al. (2011). The cosmic ray contribution was calculated after Prescott \& HutTon (1994), using appropriate positional coordinates and approximate estimate of average sediment thickness. A moisture content of $\delta=1.15 \pm 0.05$ (see Zimmerman 1971, LANG ET AL. 2003, ZöLler et al. 2013) was assumed for all samples with respect to hydromorphic features. This was despite the fact that the measured actual moisture content was lower with values between 1.09 and 1.11. An alpha efficiency factor (a-value) of $0.08 \pm 0.02$, derived as an average from numerous data from loess (see

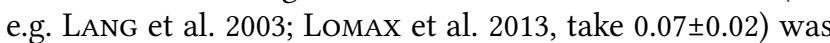
assumed for all polymineral fine-grain samples. An a-value of $0.035 \pm 0.05$ was employed in dose-rate calculations for the quartz middle grain fraction (cf. LAI et al. 2008).

Analytical results for concentrations of radio-elements are given in Table 1 and the calculated dose-rate (in Gy/ka) for moist samples and the cosmic ray dose contributions are provided in Table 2 (data in all tables with $1 \sigma$ uncertainty).

\subsection{IRSL dating results}

All IRSL samples yielded shine-down plateaus suggesting sufficient bleaching of the IRSL signal during and prior to deposition of the loess. The fading tests resulted in ratios between $1.04 \pm 0.08$ and $0.98 \pm 0.06$. Therefore, no correction for athermal fading was applied.

Equivalent doses together with effective dose-rates and the resulting IRSL ages are presented in Table 3 together with their $1 \sigma$ uncertainty. While IRSL results generally provide increasing ages with depth, the IRSL ages of samples BT 1010 and 1013 do not conform with this trend and were significantly younger than their respective overlying samples (Figure 3). The location on a plateau and the sample being buried under several meters of loess, rules out major sedimentological disturbances as a cause. According to the fading tests, short-term athermal fading can be precluded 
as a possible reason. ${ }^{1}$ The dosimetry is not different from the other samples and radioelement concentrations (Table 1) and thus do not indicate different sediment source areas, which could have resulted in the vastly different alpha sensitivity necessary for such age discrepancies. No explanation can be presently put forward, and therefore these age estimates were considered as outliers, and excluded from further interpretation, pending further research. Given such an ambiguity, OSL dating using pure quartz separates from the identical sample material was carried out in order to verify the reliability of IRSL dating.

\subsection{OSL dating results}

Effective dose-rates for middle grain quartz are lower than for feldspar-dominated fine-grains due to significantly lower a-values. The equivalent doses together with effective dose-rates and resulting OSL ages are presented in Table 5 with $1 \sigma$ uncertainties. It is noteworthy that samples BT 1010 and 1013, which provided suspicious IRSL dating results, yielded OSL ages which are consistent with OSL ages for samples stratigraphically located above and below, respectively. Furthermore, no significant age inversion of OSL ages with respect to stratigraphy was observed, and from this point of view none of the OSL ages is therefore suspected to be underestimated.

\section{Comparison of OSL and IRSL dating results}

Radiocarbon ages for the main archaeological layer (ANTLWeiser et al. 2010, Nigst \& ANTL-Weiser 2012) were calibrated with the "Calib Rev 6.1.1" program (STUIVER \& REIMER 1993), employing the IntCal09 calibration curve (REIMER et al. 2009). Calibration results are given in Table 4 and probability distributions are plotted in Figure 2. For the main archaeological layer $\mathrm{AH} 4$ we calculated a summed probability ${ }^{14} \mathrm{C}$ age of 30405 to $29162 \mathrm{cal}$ BP $2 \sigma$ (see Table 4).

An age-depth plot of IRSL, OSL and calibrated ${ }^{14} \mathrm{C}$ ages is shown in Figure 3. Two IRSL ages from samples above AH4 of $23.3 \pm 1.6 \mathrm{ka}$ (BT 1008) and $17.7 \pm 1.3 \mathrm{ka}$ (BT 1007) are younger than the calibrated ${ }^{14} \mathrm{C}$ ages, while IRSL results down to $150 \mathrm{~cm}$ below AH4 are still in accordance within uncertainties. The OSL ages are all in agreement with radiocarbon data, except for the lowermost sample (BT 1014), which is significantly older. The OSL ages are all consistent with the stratigraphy and samples BT 1008 and 1009, which are bracketing AH4, agree with the radiocarbon ages. In general, uncertainties for OSL ages (middle grains) are remarkably larger than for IRSL dating due to relatively large scatter of equivalent doses obtained from single aliquots. This is in accordance with previous observations (e.g., Fuchs et al 2012). In Figure 4, the OSL and the

1) The measurements for these two samples were repeated in order to confirm the results. An identical equivalent dose (ED) was obtained for BT 1010_new (76.8 \pm 3.6 Gy) and, thus, the identical apparent age. In case of BT 1013 the ED changed significantly from $91.9 \pm 1.3$ Gy to 105.7 \pm 2.3 Gy for reasons unknown so far (BT 1013_new), whereas the apparent ages of $23.1 \pm 1.6$ and $26.6 \pm 2.9 \mathrm{ka}$, respectively, agree within uncertainties. Nevertheless, the apparent IRSL age of BT 1010_new remains a significantly underestimated outlier in an internal consistency check, where the identical systematic uncertainties are excluded. accepted IRSL dating results with their $1-\sigma$ errors are plotted together with the stratigraphy of the sampled profile. Whereas OSL and the accepted IRSL ages agree within the error limits for all samples below AH4, this is not the case for sample BT 1007 located stratigraphically above AH4.

As mentioned above, significant anomalous fading as a reason for the age underestimates of this IRSL age with respect to the OSL age is precluded. The fading experiment would have revealed at least short term fading as it equals

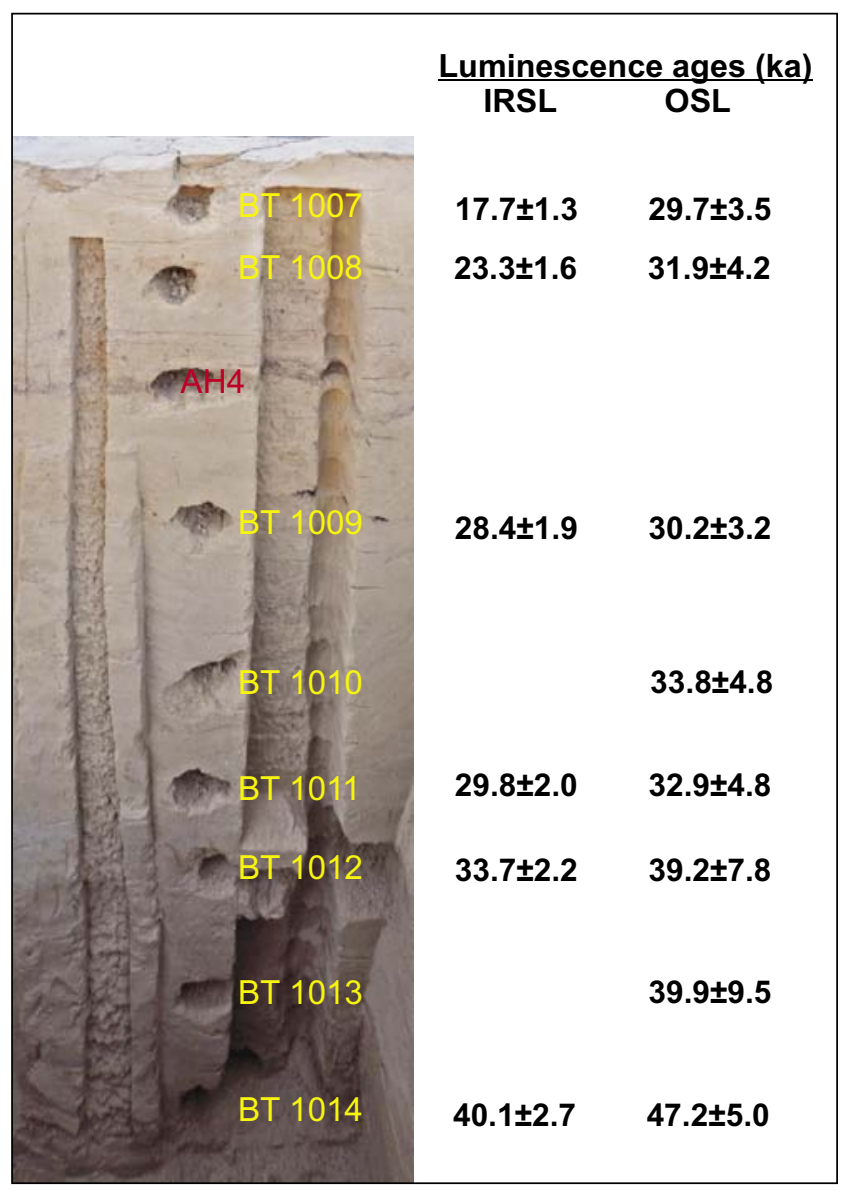

Fig. 4: Sample positions along the profile and comparison of OSL and IRSL dating results.

Abb. 4: Positionen der Proben im Profil und Vergleich von OSL- und IRSLDatierungsergebnissen.

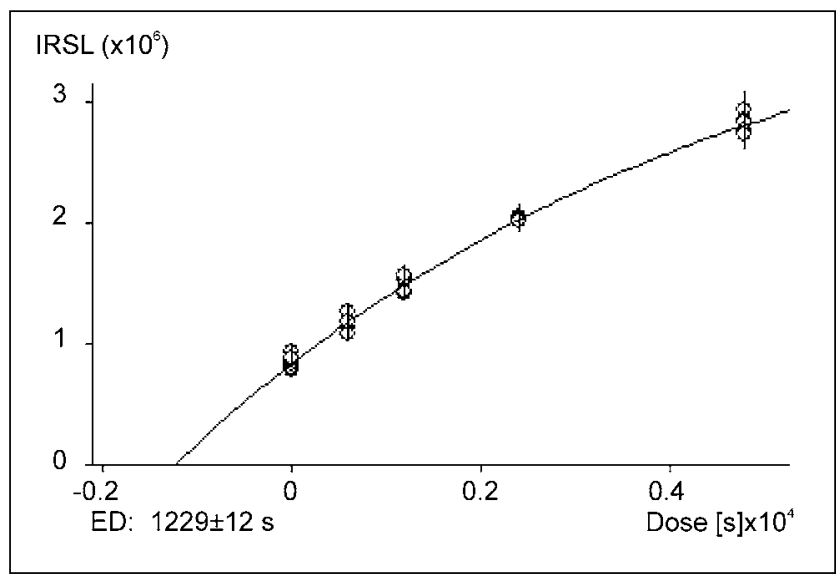

Fig. 5: Additive IRSL dose-response curve (MAAD) for sample BT 1012. Abb. 4: Additive IRSL-Wachstumskurve (MAAD) für Probe BT 1012 
Tab. 1: Radioelement concentrations.

Tab. 1: Konzentrationen der Radioelemente.

\begin{tabular}{|c|c|c|c|c|c|c|}
\hline Sample no. & Th & $\delta$ Th & U & $\delta U$ & K & $\delta K$ \\
\hline & [ppm] & [ppm] & [ppm] & [ppm] & [\%] & [\%] \\
\hline BT 1008 & 9.12 & 1.31 & 4.10 & 0.40 & 1.59 & 0.16 \\
\hline BT 1010 & 7.63 & 0.97 & 4.15 & 0.30 & 1.65 & 0.17 \\
\hline BT 1011 & 9.27 & 0.95 & 3.67 & 0.29 & 1.76 & 0.18 \\
\hline BT 1014 & 9.35 & 1.14 & 3.32 & 0.35 & 1.78 & 0.18 \\
\hline
\end{tabular}

Tab. 2: Dose-rates for moist samples assuming $\delta=1.15$

Tab. 2: Dosisleistungen für feuchte Proben bei $\delta=1.15$

\begin{tabular}{|c|c|c|c|c|c|c|c|c|c|}
\hline Sample no. & $D_{\alpha \text { moist }}$ & $\delta\left[D_{\alpha \text { moist }}\right]$ & $D_{\beta \text { moist }}$ & $\delta\left[\mathrm{D}_{\beta \text { moist }}\right]$ & $D_{\gamma \text { moist }}$ & $\delta\left[\mathrm{D}_{\gamma \text { moist }}\right]$ & Depth & $\mathrm{D}_{\mathrm{cosm}}$ & $\delta\left[D_{\operatorname{cosm}}\right]$ \\
\hline & [Gy/ka] & [Gy/ka] & [Gy/ka] & [Gy/ka] & [Gy/ka] & [Gy/ka] & {$[\mathrm{m}]$} & [Gy/ka] & [Gy/ka] \\
\hline BT 1007 & 9.96 & 0.66 & 1.78 & 0.15 & 1.15 & 0.10 & 1.5 & 0.195 & 0.02 \\
\hline BT 1008 & 8.09 & 0.55 & 1.81 & 0.15 & 1.10 & 0.09 & 1.7 & 0.193 & 0.02 \\
\hline BT 1009 & 9.00 & 0.61 & 1.84 & 0.15 & 1.15 & 0.09 & 2.4 & 0.186 & 0.02 \\
\hline BT 1010 & 6.88 & 0.48 & 1.82 & 0.15 & 1.06 & 0.08 & 2.8 & 0.182 & 0.02 \\
\hline BT 1011 & 8.15 & 0.55 & 1.88 & 0.16 & 1.10 & 0.08 & 3.1 & 0.179 & 0.02 \\
\hline BT 1012 & 9.71 & 0.65 & 2.02 & 0.17 & 1.23 & 0.09 & 3.4 & 0.176 & 0.02 \\
\hline BT 1013 & 9.54 & 0.63 & 1.89 & 0.16 & 1.16 & 0.09 & 3.7 & 0.173 & 0.02 \\
\hline BT 1014 & 8.16 & 0.55 & 1.85 & 0.16 & 1.08 & 0.09 & 4.0 & 0.170 & 0.02 \\
\hline
\end{tabular}

Tab. 3: Equivalent doses (ED), effective dose-rates (Gy/ka) and IRSL ages (ka). Ages in italics are considered as outliers and discarded from further discussion.

Tab. 3: Äquivalenzdosen (ED), effektive Dosisleistungen und IRSL-Alter (ka). Alter in Kursivschrift werden als Ausreißer betrachtet und in der weiteren Diskussion nicht berücksichtigt.

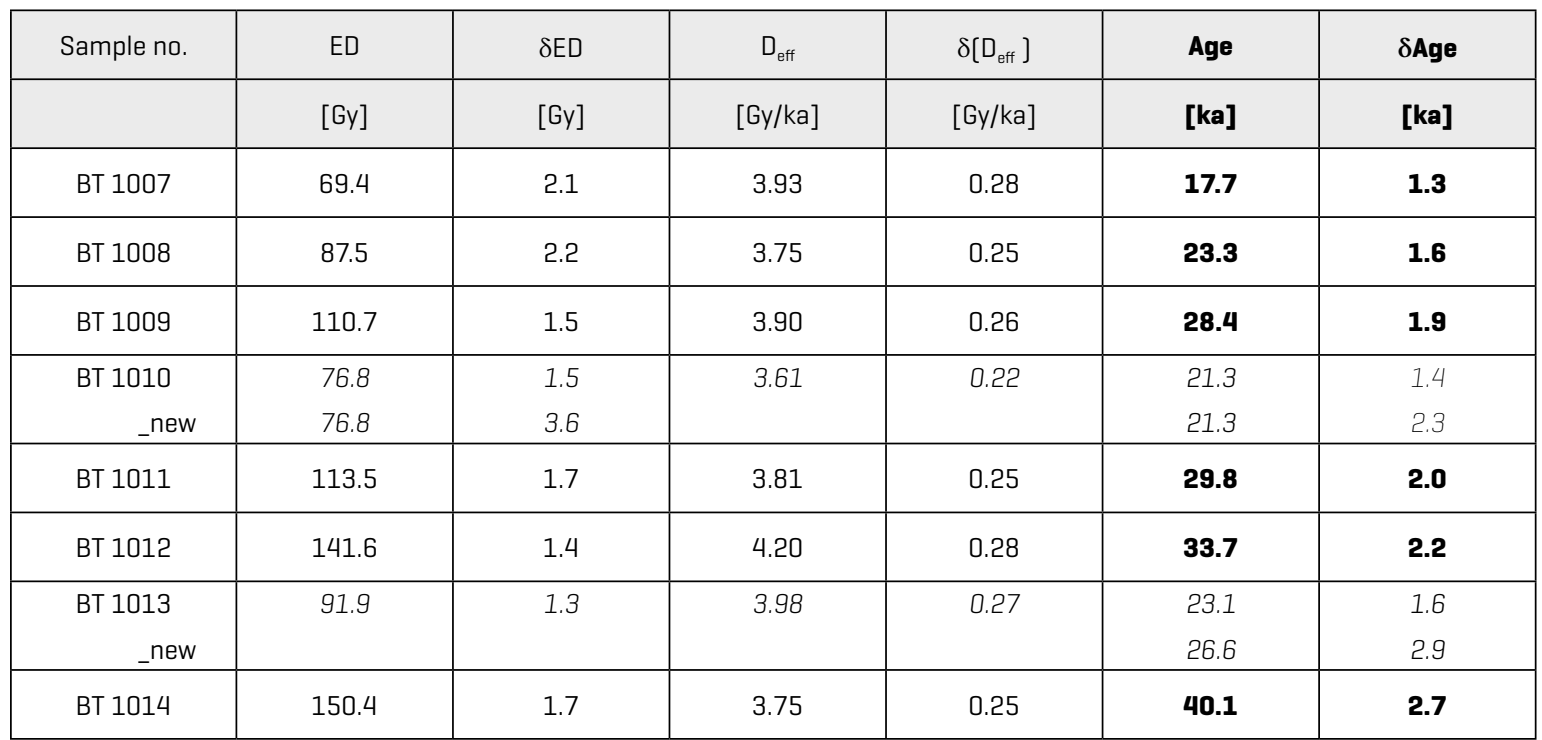


4 weeks of room temperature storage. We cannot preclude, however, mid- or long-term fading (XIE \& Aitken 1991) which cannot be detected in the laboratory within the available time. Inspection of the shapes of luminescence decay and growth curves (Figure 5) did not reveal any clues, where especially the latter are well below the onset of saturation and therefore do not appear to be critical. The same applies to possible discrepancies in alpha sensitivity. Provided the uniformity of the source material, which is indicated by the lack of variability in radioelement concentration, a significant discrepancy in the alpha sensitivity is considered most unlikely as reason. We like to mention, however, that during sampling in the field we observed crotovinas extending downwards almost to the upper archaeological layer and causing some problems during sampling. Furthermore, the area was used as a vineyard in previous times and remnants of deep roots of grapevines were detected in the uppermost loess. Even if sampling tried to steer clear of crotovinas and tracks of former grapevines we cannot be totally certain to have entirely avoided sampling material affected by bioturbation. Thus, the obtained age, possibly including the other sample located above AH4 (BT 1008) may be a mixed age and thus underestimating the original deposition age of the loess. It would be a surprise, however, if only fine grains contaminated the loess due to bioturbation and not coarse silt grains used for OSL dating. This question will be studied further using soil micromorphology during ongoing research by other members of the working group.

The IRSL ages from above AH4 may suggest erosional hiatuses or strongly reduced sedimentation rate. Although traces of solifluction were detected in this part of the section, other possible reasons for these rather young apparent ages need to be identified. As far as AH4 and deeper horizons are concerned, we can state that within uncertainties IRSL and OSL ages are consistent with calibrated radiocarbon ages on charcoal which yielded congruent results from different laboratories (ANTL-WEISER et al. 2010, Nigst \& Antl-Weiser 2012) and an age of ca. $30 \mathrm{ka}$ for AH4 is confirmed by luminescence dating results. The chronostratigraphic position of the loess above the upper archaeological layer so far remains a matter of debate.

\section{Discussion}

The luminescence dating results for the Grub-Kranawetberg site have implications for the regional loess stratigraphy and the supposed relation of human occupation patterns to specific palaeoecologies. If the uppermost OSL ages correctly reflect the deposition ages of the loess above AH4 the entire exposed loess sequence presumably accumulated during a time period corresponding to a late phase of Marine Isotopic Stage MIS 3. The two uppermost IRSL ages, however, argue for deposition of the loess above the upper archaeological layer during MIS 2.

\section{Constraints for palaeoecology}

The archaeological layer AH4 overlies a brownish interstadial palaeosol which appears to be coeval with the nearby "Stillfried B" palaeosol at its type locality. The loess in which AH4 is embedded exhibits, however, features of hydromor- phic soils and of solifluction (as so far no indication of harsh permafrost conditions was observed in this layer we were cautious in using the term gelifluction). These observations as well as preliminary malacological results (ANTL-WEISER et al. 1997) indicate a climatic deterioration (cooling) after the thermal optimum of the interstadial for the time of occupation. The presence of humans in such palaeoecological conditions is usually neglected, based on an oversimplifying geodeterministic view that in general Upper Palaeolithic humans inhabited Central Europe at the onset or during thermal optimum of interstadials and withdrew at the onset of climatic cooling. Instead, moister and cooler climate at the onset of a stadial could have triggered higher bioproductivity of the landscape with respect to a summer-dry loess steppe and, thus, better conditions for game (e.g., ZECH $\mho$ Hintermaier-Erhard 2002, p. 12; Schultz 2002). Möller \& ThANNHEISER (2011) point out that tundra soils of moist habitat can produce a high amount of below-ground phytomass "which is important for plant growth and for building up soil organic matter” (p. 255).

In many classical loess-palaeosol sequences of Central Europe the time span between ca. 30 and ca. $26 \mathrm{ka}$ is poorly resolved due to erosion (e.g., Zöller \& SEMmel 2001, ZöLLER et al. 2004). Convincing evidence for rapid loess sedimentation starting around $30 \mathrm{ka}$ ago (i.e., late MIS 3) with intercalation of up to 4 or 5 tundra gley soils was reported from the Nussloch site, Germany (AnToine et al. 2009) and from the Dolní Věstonice (with less thickness) in, Czech Republic (Fuchs et al. 2012), as also from the KremsWachtberg site, Austria (Lomax et al. 2013, ZöLler et al. 2013). In the upper part of the relevant section at Nussloch, Antoine et al. (2009) observed "cryo-dessication micro cracks" (layer 24, see legend to their Figure 2). Even if Nussloch is situated ca. $630 \mathrm{~km} \mathrm{WNW}$ of Grub the drastic climatic cooling starting around 30 ka ago must have affected the surroundings of Grub and Stillfried as well. LÜTHGENS \& BösE (2011) suggest that the ice advance of the "Brandenburg phase" (local glacial maximum) of the last glaciation (Weichselian) occurred during the time interval under question. This dramatic palaeoecological event in northern Central Europe may be reflected some Central European loess areas.

Constraints for Austrian and European loess stratigraphy The chronostratigraphic position of the "Stillfried B" palaeosol has been a matter of debate (TERHORST et al. 2011). At the "classical" site in the north-western corner of the former Stillfried brickyard (N $48^{\circ} 24^{\prime} 32,4^{\prime \prime}$, E $16^{\circ} 50^{\prime} 31,6^{\prime \prime}$ ) the substratum of the weakly developed "Stillfried B" soil was dated 29.8 \pm 3.7 ka by TL (ZöLLER et al. 1994). It directly overlies Rissian loess (HAMBACH \& ZöLLER, unpublished results) from which it is separated by an erosional hiatus. For this reason, the "Stillfried B" pedocomplex is supposed to have developed only with its youngest part at this site. PeticzKa et al. (2010) described a "revised profile" from the western part of the abandoned brickyard which appears stratigraphically more complete and resembles the stratigraphy of the GrubKranawetberg excavation. Using field methods mentioned by Petitzka et al. (2010) the authors distinguish 3 fossil BC horizons at their "Stillfried B 2005" site which corresponds to 3 buried interstadial soils at Grub-Kranawetberg. Unfor- 


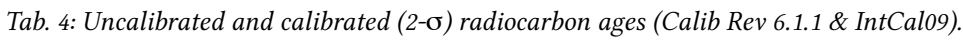

* no laboratory number available

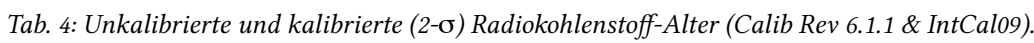

* keine Labornummer verfügbar

\begin{tabular}{|c|c|c|c|c|c|}
\hline Archaeological & relative & Laboratory & uncalibrated & error & calibrated \\
\hline layer & depth & code & age $[\mathrm{aBP}]$ & [a] & age range [a calBP] \\
\hline Upper layer & 10 & GrA-28184 & 25640 & 160 & 30939 - 30191 \\
\hline \multirow{3}{*}{ Main layer $\mathrm{AH} 4$} & 0 & GrA-9066 & 24830 & 230 & 30284 - 29257 \\
\hline & 0 & GrA-9065 & 24930 & 240 & 30321 - 29359 \\
\hline & 0 & GrA-9063 & 24620 & 230 & $30189-28748$ \\
\hline
\end{tabular}

Tab. 5: Equivalent doses (ED), effective dose-rates (Gy/ka) and quartz OSL ages (ka)

Tab. 5: Äquivalenzdosen (ED), effektive Dosisleistungen und Quarz-OSL-Alter (ka)

\begin{tabular}{|c|c|c|c|c|c|}
\hline Sample no. & ED & $\delta_{\mathrm{ED}}$ & $D_{\text {eff }}$ & Age & $\delta_{\text {Age }}$ \\
\hline & [Gy] & [Gy] & [Gy/ka] & [ka] & [ka] \\
\hline BT 1007 & 101 & 9 & 3.40 & 29.7 & 3.5 \\
\hline BT 1008 & 106 & 11 & 3.31 & 31.9 & 4.2 \\
\hline ВТ 1009 & 103 & 7 & 3.41 & 30.2 & 3.2 \\
\hline BT 1010 & 108 & 13 & 3.23 & 33.8 & 4.8 \\
\hline BT 1011 & 111 & 14 & 3.37 & 32.9 & 4.8 \\
\hline BT 1012 & 144 & 28 & 3.68 & 39.2 & 7.8 \\
\hline BT 1013 & 138 & 27 & 3.47 & 39.9 & 9.5 \\
\hline ВТ 1014 & 156 & 16 & 3.31 & 47.2 & 5.0 \\
\hline
\end{tabular}

tunately, no dating results have been published so far from the "Stillfried B 2005" site. The time of this pedocomplex at the Grub-Kranawetberg excavation is bracketed by our IRSL ages between $28.4 \pm 1.9 \mathrm{ka}$ and $40.1 \pm 2.7 \mathrm{ka}$ and by our OSL ages between $30.2 \pm 3.2 \mathrm{ka}$ and $47.2 \pm 6.0 \mathrm{ka}$. Thus, the GrubKranawetberg site and the "Stillfried B 2005" site both appear well-suited to complete the Austrian loess stratigraphy in the period between ca. 40 and ca. 30 ka (MIS 3, upper part) by increasing the number of observed soils from one (Stillfried B) to a complex of three paleosols. Furthermore, our new dating results can inform the discussion on the correlation of the Stillfried B palaeosol with loess stratigraphies from other European areas, such as Southern Moravia (Fuchs et al. 2012), Serbia (Fuchs et al. 2008), Hungary (ZöLLER et al. 1994, Thiel et al. 2013), Austria (Thiel et al. 2011), Ukraine (Rousseau et al. 2011), and Germany (Antoine et al. 2009, KADEREIT et al. 2013). The pedo-complex at Grub-Kranawetberg below AH4 and the revised "Stillfried B 2005" section appear to be coeval with interstadial soils or pedocomplexes in the mentioned areas. But with respect to palaeo-moisture conditions, palaeo-temperatures and sedimentation rates in the different regions the palaeosols manifest different soil typologies ranging from tundra-gleys or (sub-) arctic cambisols to chernozems. It may prove of particular interest that the range of apparent OSL ages bracketing the lowermost soil of the Grub-Kranawetberg pedocomplex (samples BT 1013 and 1014) includes the TL age of $43 \pm 4$ ka for the substratum of the "MF1" palaeosol (chernozem) in Hungary (ZöLLER et al. 1994, cf Thiel et al. 2013). On the other hand, high sedimentation rates and locally dry climate impeded well-distinguishable interstadial palaeosols at the Krems-Wachtberg site. Therefore, an equivalent of the Stillfried B pedocomplex cannot be clearly identified so far at Krems-Wachtberg, although the same age range is covered (TERHORST et al. 2013).

\section{Conclusions}

The application of an IRSL-MAAD protocol for polymineral fine grain loess has once more (as in e.g. LANG et al. 2003; Fuchs et al. 2008) yielded age estimates congruent in their majority with OSL and radiocarbon dating. While this in itself indicates the absence of anomalous fading of 
the feldspar luminescence component used, a fading test neither did show any loss of signal, and it appears that the occurrence of feldspar fading might be related to detection (here: blue band wavelength) and protocol (here: MAAD) used. OSL ages from quartz middle grains are, however, stratigraphically consistent without exception and also agree with radiocarbon dating results.

Luminescence dating confirms an age of ca. $30 \mathrm{ka}$ for the main archaeological horizon AH4. According to proxy data, the main human occupation documented in level AH4 occurred after the thermal optimum of an interstadial at the onset of colder and moister conditions. A threefold complex of interstadial soils underlies the archaeological layers of Lower Gravettian age. This pedocomplex developed in a time span ranging from $\geq 40 \mathrm{ka}$ to ca. $30 \mathrm{ka}$ and includes the palaeosol known as "Stillfried B" soil. The pedocomplex at the Grub-Kranawetberg site appears, however, coeval with a nearby pedocomplex introduced as "Stillfried B 2005" (Peticzka et al. 2010) and with interstadial palaeosols or pedocomplexes of different typologies in various European loess regions. The Grub-Kranawetberg site is, thus, wellsuited to complete the Austrian loess stratigraphy for the upper part of MIS 3 and to refine correlation with neighbouring European loess areas. For the loess overlying the archaeological layers at the Grub-Kranawetberg site a significant difference between IRSL and OSL ages still exists which calls for further investigations, e.g. the application of the NCF protocol for quartz OSL (SINGHVI et al. 2011).

\section{References}

ANTL-Weiser, W. (2013): The inventory of archaeological Horizon 4 and 3 and the loess section of Grub-Kranawetberg, a Gravettian camp site in Lower Austria. - E\&G Quaternary Science Journal (this volume).

ANTL-WeIsER, W. (2008): Grub/Kranawetberg and Ollersdorf/Heidenberg (Lower Austria) - two Gravettian camp Sites in Eastern Austria. Wiss. Mitt. Niederösterr. Landesmuseum, 19: 59-78.

Antl-Weiser, W., Fladerer, F. A., Nigst, P.R. \& Verpoorte, A. (2010): Grub/Kranawetberg (Lower Austria) - Insights into a Gravettian Micro-Region in Eastern Austria. - Mitteilungen der Prähistorischen Kommission, 72: 231-243.

Antl-Weiser, W., Fladerer, F.A., Peticzka, R., Stadler, F. C. \& Verginis, S. (1997): Ein Lagerplatz eiszeitlicher Jäger in Grub bei Stillfried. Archäologie Österreichs 8/1, 1997: 4-20.

Antoine, P., Rousseau, D.-D., Moine, O., Kunesch, S., Hatté, C., Lang, A., Tissoux, H. \& ZöLler, L. (2009): Rapid and cyclic aeolian deposition during the Last Glacial in European loess: a high-resolution record from Nussloch, Germany. - Quaternary Science Reviews, 28: 2955-2973.

Berger, G. (1988): Dating Quaternary events by luminescence. - In: D.J EASTERBRooK (ed), Datingh Quaternary Sediments. - Geological Society of America, Special Paper 227: 13-50.

Fuchs, M., Straub, J. \& Zöller, L. (2005): Residual luminescence signals of recent river flood sediments: A comparison between quartz and feldspar of fine- and grain-sized sediments. - Ancient TL, 23: 25-20.

Fuchs, M., Rousseau, D.-D., Antoine, P., Hatté, C., Gauthier, C., Marković, S. \& Zöller, L. (2008): Chronology of the Last Climatic Cycle (Upper Pleistocene) of the Surduk loess sequence, Vojvodina, Serbia. - Boreas, 37: 66-73.

Fuchs, M., Kreutzer, S., Rousseau, D. D., Antoine, P., Hatté, C., Lagroix, F., Moine, O., Gauthier, C., Svoboda,J. \& LisÁ, L. (2012): The loess sequence of Dolní Veštonice, Czech Republic: A new OSL-based chronology of the Last Climatic Cycle. - Boreas, DOI: 10.1111/j.15023885.2012.00299.x. ISSN 0300-9483.

Guerin, G., Mercier, N. \& Adamiec, G. (2011): Dose-rate conversion factors: update. - Ancient TL, 29: 5-8.

Kadereit, A., Kind, C.-J. \& WAgner, G.A. (2013): The chronological position of the Lohne Soil in the Nussloch loess section - re-evaluation for a European loess-marker horizon. - Quaternary Science Reviews, 59: $67-86$.

Lai, Z. P., Zöller, L., Fuchs, M. ひ H. Brückner, H. (2008): Alpha efficiency determination for OSL of quartz extracted from Chinese loess. - Radiation Measurements, 43: 767-70.

Lang, A., Hatte, C., Rousseau, D.-D., Antoine, P., Fontugne, M., ZölleR, L. \& HAMBACH, U. (2003): High-resolution chronologies for loess: comparing AMS ${ }^{14} \mathrm{C}$ and optical dating results. - Quaternary Science Reviews 22: 953-959.

Lomax, J., Fuchs. M., Preusser, F. \& Fiebig, M (2013): Luminescence based loess chronostratigraphy of the Upper Palaeolithic site KremsWachtberg, Austria. - Quaternary International, DOI: 10.1016/j. quaint.2012.10.037

Lüthgens, C. \& Böse. M. (2011): Chronology of Weichselian main ice marginal positions in north-eastern Germany. - E\&G Quaternary Science Journal, 60: 236-247.

Mauz, B., Bode, T., Mainz, E., Blanchard, H., Hilger, W., Dikau, R. \& ZÖLLER, L. (2002): The luminescence dating laboratory at the University of Bonn: Equipment and procedures. - Ancient TL, 20: 53-61.

Möller, I. \& Thannheiser, D. (2011): Ecosystem Dynamiocs of Subpolar and Polar Regions. - In: Millingten, A.C:, Blumler, M.A. \& SchickHOFF, U. (eds.) - Biogeography. 598 p., SAGE.

Murray, A.S. \& Wintle A.G. (2000): Luminescence dating of quartz using an improved singlealiquot regenerative-dose protocol. - Radiation Measurements, 33: 57-73.

Nigst, P.R. \& ANTL-Weiser, W. (2012): Les structures d'occcupation gravettiennes en Europe centrale: le cas de Grub/Kranawetberg, Autriche. - L'anthropologie, 116: 639-664.

Peticzka, R., Holawe, F. \& Riegler, D. (2010): Structural analyses on the modified paleosol-sequence of "Stillfried B" with high resolution measurements of selected laboratory parameters. - Quaternary International, 222: 168-177.

Prescott, J.R. \& Hutton, J.T. (1994): Cosmic ray contributions to dose rates for luminescence and ESR dating: large depths and long term variations. - Radiation Measurements, 23: 497-500.

Reimer, P., Baillie, M., Bard, E., Bayliss, A., Beck, J., Blackwell, P., Bronk Ramsey, C., Buck, C., Burr, G., Edwards, R., Friedrich, M., Grootes, P., Guilderson, T., Hajdas, I., Heaton, T., Hogg, A., Hughen, K., Kaiser, K., Kromer, B., McCormac, F., Manning, S., Reimer, R., Richards, D., Southon, J., Talamo, S., Turney, C., van Der Plicht, J. \& Weyhenmeyer, C. (2009): IntCal09 and Marine09 Radiocarbon Age Calibration Curves, 0-50,000 Years cal BP. - Radiocarbon, 51: 1111-1150.

Rousseau, D.-D., Antoine, P., Gerasimenko, N., Sima, A., Fuchs, M. Hatté, C., Moine, O. \& Zöller, L. (2011): North Atlantic abrupt climate events of the last glacial period recorded in Ukrainian loess deposits. - Climate of the Past, 7: 221-234.

Schultz, J. $\left(2002^{3}\right)$ : Die Ökozonen der Erde. - Stuttgart (Ulmer UTB).

Singhvi, A., Stokes, S., Chauhan, N., Nagar, Y. \& Jaiswal, M. (2011): Changes in natural OSL sensitivity during single aliquot regeneration procedure and their implications for equivalent dose determination. - Geochronometria 38: 231-241.

Stuiver, M. \& Reimer, P. J. (1993): Extended ${ }^{14} \mathrm{C}$ data base and revised CALIB $3.0{ }^{14} \mathrm{C}$ age calibration program. - Radiocarbon, 35: 215-230.

Terhorst, B., Thiel, C., Peticzka, R., Sprafke, T., Frechen, M., Fladerer, F.A., Roetzel, R. \& Neugebauer-Maresch, C. (2011): Casting new light on the chronology of the loess/palaeosol sequences in Lower Austria. - E\&G Quaternary Science Journal, 60: 270-277.

Terhorst, B., Kühn, P., Damm, B., Hambach, U., Meyer-Heintze, S. \& SEdov, S. (2013): Paleoenvironmental fluctuations as recorded in the loess-paleosol sequence of the Upper Paleolithic site Krems-Wachtberg. - Quaternary International (2013), DOI: 10.1016/j.quaint.2013.03.045

Thiel, E., Terhorst, B., Jaburová, I., Buylaert, J.-P., Murray, A.S. Fladerer, F.A., Damm, B., Frechen, F. \& Ottner, F. (2011): Sedimentation and erosion processes in Middle to Late Pleistocene sequences exposed in the brickyard of Langenlois/Lower Austria. - Geomorphology,135: 295-307.

Thiel, C., Horváth, E. \& Frechen, M. (2013): Revisiting the loess/palaeosol sequence in Paks, Hungary: A post-IR IRSL based chronology for the 'Younger Loess Series'. - Quaternary International (2013), DOI: 10.1016/j.quaint.2013.05.045

WAtERs, M.R. (1996): Principles of Geoarchaeology. - 398 p.; Tucson (The University of Arizona Press).

Xie, J., \& Aitken, M.J. (1991): The hypothesis of mid-term fading and its trial on Chinese loess. - Ancient TL, 9: 21-25. 
Zech, W. ¿ Hintermaier-Erhard, G. (2002): Böden der Welt. - 120 p. Heidelberg, Berlin (Spektrum)

Zimmerman, D.W. (1971): Thermoluminescent dating using fine grains from pottery. - Archaeometry, 13, 29-52.

Zöller, L. \& PERNICKA, E. (1989): A note on overcounting in alpha-counters and its elimination. - Ancient TL, 7: 11-14.

Zöller, L. \& Semmel, A. (2001): 175 years of loess research in Germany long records and "unconformities". - Earth Science Reviews, 54: 19-28.

Zöller, L., Oches, E. A. \& McCoy, W. D. (1994): Towards a revised chronostratigraphy of loess in Austria with respect to key sections in the
Czech Republic and in Hungary. - Quaternary Geochronology (Quaternary Science Reviews), 13: 465-472.

ZÖLler, L., RousseAu, D.-D., JäGER, K.-D. \& KuKLA, G. (2004): Last interglacial, Lower and Middle Weichselian - a comparative study from the Upper Rhine and Thuringian loess areas. - Z. Geomorph. N.F., 48: 1-24.

Zöller, L., Richter, D., Blanchard, H., Einwögerer, T., HÄNdel, M. \& Neugebauer-Maresch, C. (2013): Our oldest children - age constraints for the Krems-Wachtberg site obtained from various thermoluminescence dating approaches. - Quaternary International, DOI 10.1016/j.quaint.2013.05.003 